\title{
The influence of ilmenite mud waste on the hydration process of Portland cement
}

\author{
Jan Bobrowicz ${ }^{1}$ Filip Chyliński ${ }^{1}$
}

Received: 19 January 2016/ Accepted: 14 May 2016/Published online: 13 June 2016

(C) The Author(s) 2016. This article is published with open access at Springerlink.com

\begin{abstract}
The paper presents the results of research on the influence of ilmenite mud waste coming from the production of titanium dioxide on the process of cement hydration by isothermal microcalorimetry. Quantitative analysis of the waste impact on hydration heat and kinetics has been conducted. The mud shows pozzolanic properties from the early hours after contacting the waste and cement mixture with water. The optimal amount of waste addition is within the wide range from 0 to $20 \%$. From this study, it is concluded that the waste from the production of titanium dioxide may be treated as a potential replacement for cement in concrete.
\end{abstract}

Keywords Hydration heat - Pozzolanic additives - Cement hydration - Kinetics of heat development $\cdot$ Heat

development $\cdot$ Undissolved mud waste $\cdot$ Titanium dioxide

\section{Introduction}

The issues related to the impact of ilmenite mud waste, which comes from the production of titanium dioxide $\left(\mathrm{TiO}_{2}\right)$, on the hydration process of Portland cement CEM I 42.5 , which was tested using isothermal calorimetry, are presented in paper.

Due to contemporary environmental awareness, there is a need for industrial waste management to ensure that

Jan Bobrowicz

j.bobrowicz@itb.pl

Filip Chyliński

f.chylinski@itb.pl

1 Instytut Techniki Budowlanej, Warszawa ul. Filtrowa 1, Warsaw, Poland waste will not pose a potential threat and will not end up in landfill. The problems associated with the use of industrial waste still raise the interest in many social groups and require further studies.

Companies nowadays look for possibilities of waste utilization in the construction industry. There have been many attempts to dispose of waste materials containing heavy metals [1,2]. Calorimetric test method is often used to assess the compatibility of the waste with the cement matrix. The progress of cement binders' hydration, especially in the initial period of reaction with water, may be properly tested using calorimetry, because the results in the form of rate of hydration and the amount of heat generated can answer many questions related to the interaction among the components in the investigated sample. Heat of hydration illustrates the buildup of microstructure of the tested material, including many mixtures of binders and various kinds of additives [3, 4]. These studies have shown repeatedly that the use of additives in cements resulted in an interaction among mixed ingredients, giving very interesting binders and new opportunities to use them in concrete. Fly ashes from the combustion of solid fuels such as coal and lignite [5,6] and slags from steel and other productions $[7,8]$ are widely used in concrete production. There were also attempts to use MUD in the construction industry $[9,10]$.

By-products generated within the industry can contain a large variety of components, some of which may be valuable due to the favorable effect on some properties of cement composites. Waste-containing components with binding properties in grout environment can be used as a substitute for a part of cement. In addition to environmental benefits, it also gives a measurable economic effect.

For example, the use of slags in cements type CEM III (ground granulated blast furnace slag cement) gives 
cements with low heat of hydration, which can be effectively used in massive structures. All waste materials demonstrating pozzolanic properties are widely used as additives in cement and/or concrete, because they react with the components of Portland cement clinker, are involved in the formation of composite structure and have an influence on the strength of the material $[11,12]$.

Research on the utilization of various industrial wastes gives many examples of their use as raw materials for further processing in, among others, construction and agriculture. In this report, we discuss the waste generated during the production of titanium dioxide. The matter of this waste utilization has been of interest to researchers for many years, and directions of its disposing were different, e.g., in the 1980s [13], attempts have been made to dump it in the North Sea. There have also been studies suggesting using it in agriculture [14, 15] as a fertilizer. There is, however, not a lot of information on the use of ilmenite mud waste from the production process of $\mathrm{TiO}_{2}$ in the construction industry. The problem which was indicated by the authors of the previous publications was the level of radioactivity of this waste material [16-18]. Attempting such use has been limited by high radioactivity, which, for this waste exceeded acceptable standards for building products in most countries.

Of course, the level of radioactivity and chemical composition depends on the raw materials used in the production of $\mathrm{TiO}_{2}$. However, the amounts of individual chemical compounds and minerals taking part in the production process of the slurry are known and controllable. Initial analysis of available rinsed mud (R-MUD) suggested the possibility of using this waste in the process of cement mortars and concretes production. High content of silica and significant surface area of the neutralized R-MUD can cause high pozzolanic activity of this waste.

The problems associated with the use of wastes which contain substantial amounts of reactive silica, such as R-MUD, are the subject of many studies [19-22]. Our research shows that this waste contains significant amounts of silica, which makes a significant contribution to the process of building the matrix structure of the hydraulic binder.

\section{Methods}

\section{Major and trace constituents}

The major elements were measured by X-ray fluorescence (XRF) with a Philips PW 2400 system. The samples were melted with lithium tetraborate and lithium iodine to receive homogenous glass ready for measurement (Tables 1, 3).
Table 1 Chemical and phase composition and physical properties of cement used for the study

\begin{tabular}{|c|c|c|}
\hline & Characteristic & Value \\
\hline 1. & Beginning of setting time/min & 170 \\
\hline 2. & End of setting time/min & 245 \\
\hline 3. & Relevant surface $/ \mathrm{cm}^{2} \mathrm{~g}^{-1}$ & 4060 \\
\hline 4. & $\mathrm{CaO} / \%$ & 64.41 \\
\hline 5. & $\mathrm{SiO}_{2} / \%$ & 20.06 \\
\hline 6. & $\mathrm{Al}_{2} \mathrm{O}_{3} / \%$ & 4.13 \\
\hline 7. & $\mathrm{Fe}_{2} \mathrm{O}_{3} / \%$ & 3.38 \\
\hline 8. & $\mathrm{MgO} / \%$ & 0.89 \\
\hline 9. & $\mathrm{SO}_{3} / \%$ & 2.97 \\
\hline 10. & Insoluble parts & 0.89 \\
\hline 11. & $\mathrm{Na}_{2} \mathrm{O} / \%$ & 0.24 \\
\hline 12. & $\mathrm{~K}_{2} \mathrm{O} / \%$ & 0.56 \\
\hline 13. & Chlorides $/ \%$ & 0.074 \\
\hline 14. & Alkali $\mathrm{Na}_{2} \mathrm{O}$ eq. $/ \%$ & 0.61 \\
\hline 15. & $\mathrm{C}_{3} \mathrm{~S} / \%$ & 62.76 \\
\hline 16. & $\mathrm{C}_{2} \mathrm{~S} / \%$ & 10.18 \\
\hline 17. & $\mathrm{C}_{3} \mathrm{~A} / \%$ & 5.21 \\
\hline 18. & $\mathrm{C}_{4} \mathrm{AF} / \%$ & 10.28 \\
\hline
\end{tabular}

Table 2 Composition of Tellnes deposits [24]—-the raw material for production of titanium dioxide

\begin{tabular}{ll}
\hline Mineral & $\begin{array}{l}\text { Content/ } \\
\text { vol\% }\end{array}$ \\
\hline Plagioclase & 53.2 \\
Hemo-ilmenite & 28.6 \\
Ortopiroksen & 10.2 \\
Biotite & 3.9 \\
Magnetite & $0.7-2.5$ \\
Olivine, apatite, sulfates(VI) iron-nickel-cobalt- & 3.4 \\
$\quad$ copper, other accessory minerals &
\end{tabular}

The trace elements were also measured using the XRF method, but the samples were not melted but compressed without addition of any other substances (Table 4).

The mercury concentration was measured with a singlepurpose atomic absorption spectrometer TMA AMA 254 Altem system (Table 4).

\section{Calorimetrical research methodology}

The process of testing the rate and amount of heat release was carried out on mixtures containing cement and neutralized sludge. The procedure for preparing samples for test was as follows:

1. Cement and suitable mixtures in an amount of $12 \mathrm{~g}$ each were placed in special calorimetric containers made of stainless steel. 
Table 3 Concentration (\%) of major elements in sample of waste (R-MUD)

\begin{tabular}{lllllllllll}
\hline $\mathrm{SiO}_{2}$ & $\mathrm{TiO}_{2}$ & $\mathrm{Al}_{2} \mathrm{O}_{3}$ & $\mathrm{Fe}_{2} \mathrm{O}_{3}$ & $\mathrm{MnO}$ & $\mathrm{MgO}$ & $\mathrm{CaO}$ & $\mathrm{Na}_{2} \mathrm{O}$ & $\mathrm{K}_{2} \mathrm{O}$ & $\mathrm{P}_{2} \mathrm{O}_{5}$ & $\mathrm{SUM}$ \\
\hline 35.07 & 33.05 & 5.53 & 9.65 & 0.532 & 7.26 & 3.84 & 1.10 & 0.26 & 0.012 & 96.30 \\
\hline
\end{tabular}

Table 4 Concentration (ppm) of trace elements in sample of waste (R-MUD)

\begin{tabular}{lccccccccccccccc}
\hline Element & $\mathrm{As}$ & $\mathrm{Ba}$ & $\mathrm{Br}$ & $\mathrm{Ce}$ & $\mathrm{Co}$ & $\mathrm{Cr}$ & $\mathrm{Cu}$ & $\mathrm{Ga}$ & $\mathrm{Hf}$ & $\mathrm{La}$ & $\mathrm{Mo}$ & $\mathrm{Nb}$ & $\mathrm{Ni}$ \\
\hline Content in ppm & 22 & 634 & 5 & 38 & 79 & 294 & 201 & 7 & 24 & 38 & 4 & 137 & 151 \\
\hline Element & $\mathrm{Pb}$ & $\mathrm{Rb}$ & $\mathrm{Sr}$ & $\mathrm{Bi}$ & $\mathrm{Th}$ & $\mathrm{U}$ & $\mathrm{V}$ & $\mathrm{Y}$ & $\mathrm{Zn}$ & $\mathrm{Zr}$ & $\mathrm{Cd}$ & $\mathrm{Sn}$ & $\mathrm{Hg}$ \\
\hline Content in ppm & $<3$ & 11 & 220 & 3 & 28 & 5 & 795 & 19 & 504 & 1296 & 11 & $<2$ & 0.025 \\
\hline
\end{tabular}

2. Water used to prepare the test samples in the amount of $6 \mathrm{~g}$ was placed in syringes.

3. Cement and water to prepare the test samples, as well as calorimeter, were thermostated for a minimum of $24 \mathrm{~h}$ at the test temperature.

4. At the end of the thermostatic period, the steering program was activated, which controlled the course of test and recorded the results. Water was introduced by needle injections into the measuring chambers "for sample binders." Then, the sample was wetted and the process of grout hydration, with the registration of heat evolution, began.

5. The measurement was completed when the computer measured the programmed time.

Calorimetric study was carried out at $293 \mathrm{~K}\left(20{ }^{\circ} \mathrm{C}\right)$ in a special measuring system in the isothermal calorimeter [23] for at least $143 \mathrm{~h}$.

\section{Setting time}

The beginning and end of setting time of cement were tested according to EN 196-3 standard.

\section{Relevant surface}

The relevant surface of cement and R-MUD was tested according to EN 196-6 standard.

\section{Materials}

\section{Raw materials for study}

For this study, CEM I 42,5 R was used. The chemical and phase composition and physical properties of this cement are presented in Table 1 . Values in pp. 15-18 were calculated using Bouge equations.
The raw material used for the production of titanium dioxide came from Rogaland in Norway. The composition of ilmenite - the raw material used for the production of $\mathrm{TiO}_{2}$ (Table 2)-suggested that R-MUD may contain significant amounts of silica. Silica in the production process can be changed into colloidal form, with a significant specific surface, and this fact may have an important impact on its reactivity.

The MUD obtained from the production of titanium dioxide using the sulfate method after washing with water and filtering in an industrial environment (R-MUD) was characterized by a chemical composition as shown in Tables 3 and 4.

The specific surface area of the R-MUD used in the study was $8390 \mathrm{~cm}^{2} \mathrm{~g}^{-1}$ and the density $-3.15 \mathrm{~g} \mathrm{~cm}^{-3}$. Before use, the test slurry was neutralized with an addition of calcium oxide (in an amount of $<1 \%$ ) and then dried at $378 \mathrm{~K}\left(105^{\circ} \mathrm{C}\right)$ to the constant mass (Table 5).

Radioactivity levels confirmed in the study meet the criteria for construction products in Poland and are in accordance with the Regulation of the Council of Ministers dated January 2, 2007 (Dz.U. 2007 nr 4 poz. 29).

Laboratory tests were conducted on mixtures comprised of cement and sludge in the weight ratios indicated in Table 6. Tests were carried out on samples in which a specified amount of cement was replaced with the neutralized R-MUD. Because of some similarities to fly ash such as silicon dioxide content or pozzolanic activity, the amount of R-MUD replacing the cement has been selected in an arbitrary way in a range of 10-40\% (0 and $100 \%$ were reference samples).

\section{Experimental}

The calorimetric study showing the effect of the addition of R-MUD on the cement hydration process is shown in a series of diagrams (1-4). The heat of cement hydration with the addition of various amounts of R-MUD is 
Table 5 Radioactivity of sludge cleaned and neutralized with calcium oxide

\begin{tabular}{lcc}
\hline Element & Level of radioactivity/Bq kg \\
\hline Potassium K-40 & 70.59 & \\
Radium Ra-226 & 45.29 & \\
Thorium Th-232 & 125.13 & Criterion \\
\hline Marked & & \\
\hline Qualifying ratios & & $<1$ \\
$f_{1}=0.79$ & $<200$ \\
$f_{2}=45.29$ & \\
\hline
\end{tabular}

Table 6 Quantitative content of components used in the study

\begin{tabular}{lcc}
\hline Test & Cement CEM I 42,5 R/\% & R-MUD/\% \\
\hline 1 & 100 & 0 \\
2 & 90 & 10 \\
3 & 80 & 20 \\
4 & 70 & 30 \\
5 & 60 & 40 \\
6 & 0 & 100 \\
\hline
\end{tabular}

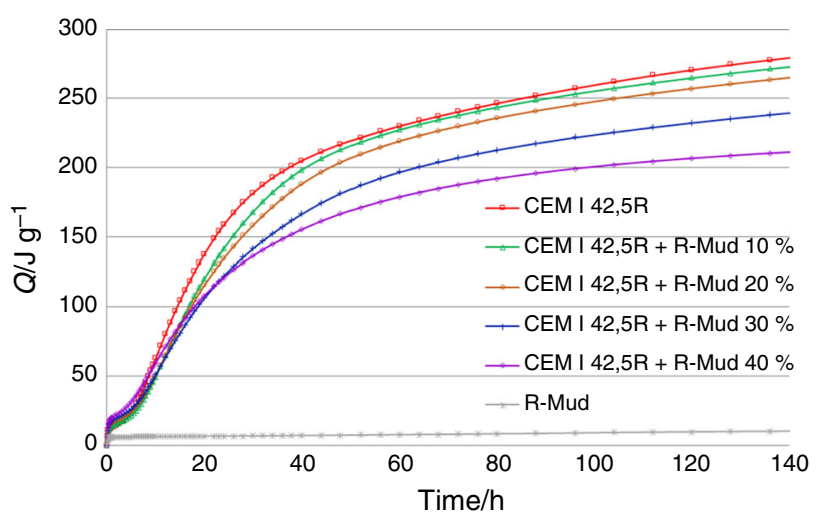

Fig. 1 Heat of hydration of cement, cement with addition of neutralized R-MUD in different amounts and R-MUD

presented in Fig. 1. The analysis of test results demonstrated that the addition of waste, as a partial replacement of cement in the test sample, did not reduce the quantity of heat registered with the isothermal calorimeter, in proportion to the addition of this material in the grout. This impact is much smaller than in a case when inert additives are used. Reduction in heat developed during the initial period of the hydration process is low when R-Mud is added to the mixture. This influence is low throughout the whole tested period, which is clearly visible when $10 \%$ or even $20 \%$ of R-MUD is used as an addition to the cement.

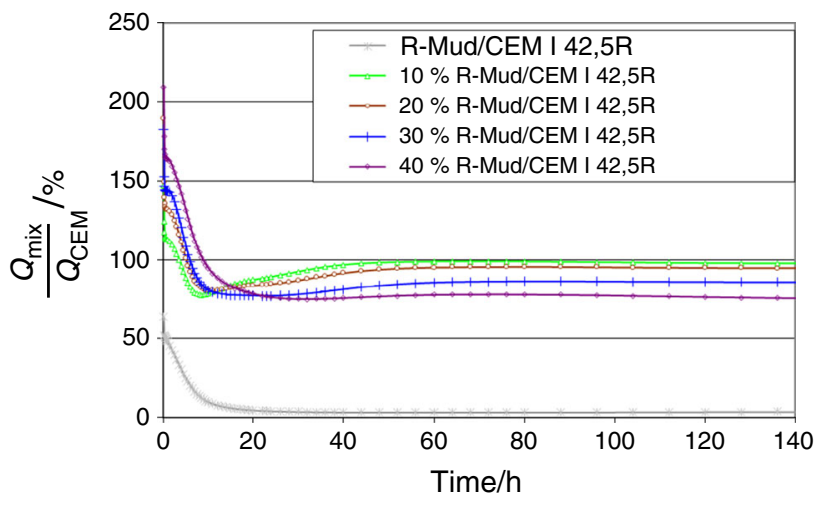

Fig. 2 Level of hydration of cement, neutralized R-MUD in different amounts, and the R-MUD in relation to the level of cement hydration

This is confirmed by the analysis presented in Fig. 2, which proved that the R-MUD is not an inert addition, but actively participates in the process of cement hydration. The amount of heat generated, measured as the ratio of heat (I-Eq. 1) which is emitted during a defined period with a mixture of cement and sludge $\left(Q\left(t_{\mathrm{i}}\right)_{\text {(mix) }}\right)$ to the heat generated during the hydration of cement in the same period $\left(Q\left(t_{\mathrm{i}}\right)_{(\mathrm{CEM})}\right)$, is not $<75 \%$ in each test. The phenomenon is clearly visible in the test in which cement was replaced by $40 \%$ of R-MUD. With the increase in cement content in the mixture, this ratio is closer to $100 \%$ (where the addition of the sludge is $10 \%$ ) (Fig. 2). These values indicate a significant participation of waste in the hydration process, already in the first hours after contacting the mixture of binder and sludge with water.

The analysis shown in Fig. 2 can be described by the formula:

$I=\frac{Q\left(t_{\mathrm{i}}\right)_{(\mathrm{mix})}}{Q\left(t_{\mathrm{i}}\right)_{(\mathrm{CEM})}} \times 100$

where $Q\left(t_{\mathrm{i}}\right)_{(\text {mix })}$-hydration heat of the mixture of R-Mud and cement after time $t, Q\left(t_{\mathrm{i}}\right)_{(\mathrm{CEM})}$-hydration heat of cement after the time $t$.

The rate of heat development (Fig. 3) also confirms the reactivity of R-MUD from the very beginning of the hydration process of the mixture. The acceleration of the heat release occurs during the first hours of the process and is visible even throughout the induction period of the hydration reaction of the binder [11]. After about $5 \mathrm{~h}$, the equalization rate of heat occurs and the biggest reactivity of cement begins, as expected. After $28 \mathrm{~h}$ of hydration, the reactivity cement without additives is smaller than that of the mixture containing $10 \%$ of R-MUD, and after $42 \mathrm{~h}$ it is also smaller than that of the mixture containing $40 \%$ of R-MUD. Practically, after about $48 \mathrm{~h}$ of hydration, the rate of heat release does not show significant differences (Fig. 4). 


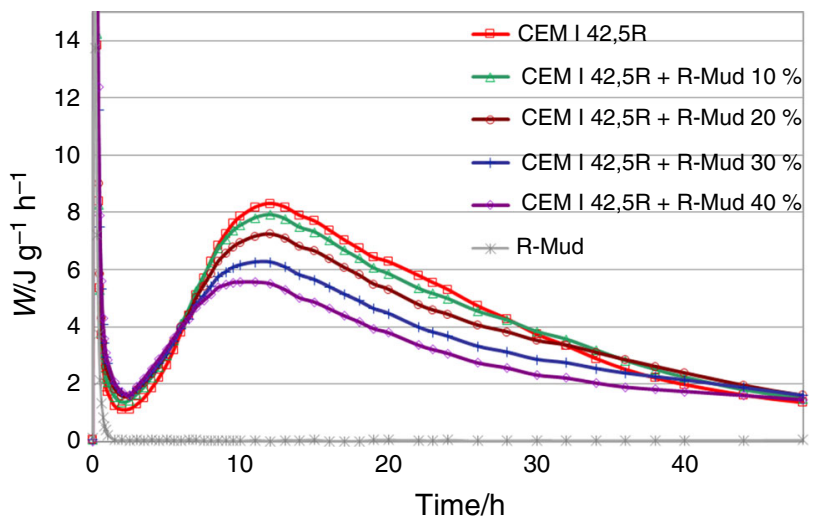

Fig. 3 Rate of heat development during hydration of cement, cement with neutralized R-MUD in different amounts, and R-MUD- $W=\frac{\mathrm{d} Q}{\mathrm{~d} t}$ $\left(\mathrm{J} \mathrm{g}^{-1} \mathrm{~h}^{-1}\right)$

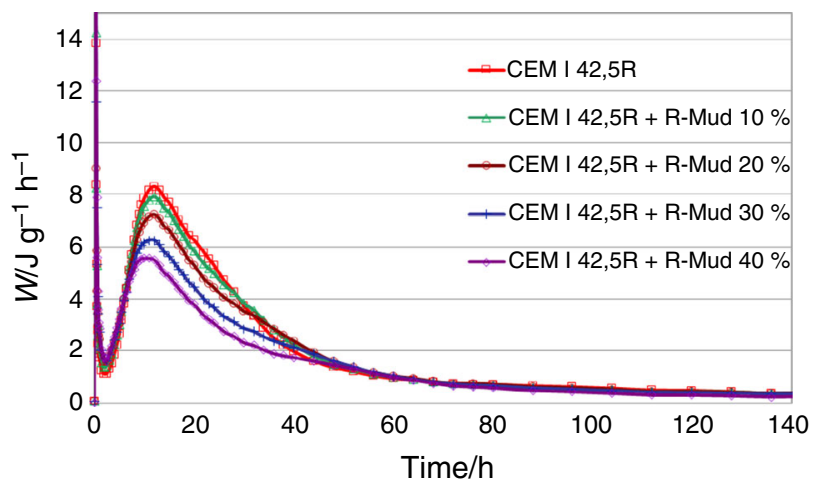

Fig. 4 Rate of heat development during hydration of cement, cement with neutralized R-MUD in different amounts, and R-MUD after the first 6 days $-W=\frac{\mathrm{d} Q}{\mathrm{~d} t}\left(\mathrm{~J} \mathrm{~g}^{-1} \mathrm{~h}^{-1}\right)$

The activity of R-MUD when mixed with water is visible only at the beginning of the process, i.e., up to about $1 \mathrm{~h}$ from adding water, when probably hydration reactions take place in the mineral waste, which have been formerly dehydrated when the sludge was being dried after neutralization (Figs. 1, 3).

The neutralization of R-MUD did not introduce a large excess of calcium oxide because the amount used to neutralize was $\mathrm{CaO}=0.75 \%$ (the total content of $\mathrm{CaO}$ in the R-MUD after neutralization was about $3.84 \%$-Table 3) and the solution is slightly acidic with $\mathrm{pH}$ of about 5 . The reaction is strongly exothermic and occurs at the very beginning of the contact between R-MUD and water, and is certainly not related to the content of calcium oxide which, due to the slightly acidic R-MUD, overreacts and appears in the form of salt. In the solution, the reactions of salt derivatives, which appear due to the added calcium oxide, cannot be excluded. It is more likely that other reactions of oxides forming the R-MUD may release a large amount of heat at the beginning of the process in contact with water.
In the first hour of hydration $5.9 \mathrm{~J} \mathrm{~g}^{-1}$ was released, while after $142 \mathrm{~h}$ the quantity reached $9.9 \mathrm{~J} \mathrm{~g}^{-1}$. The heat developed at the beginning (Figs. 1, 3) may come from the reaction of hydration of various salts contained in the sludge and water adsorption on a highly developed surface of the silica. These issues require further study.

\section{Summary and conclusions}

The study carried out confirms the usefulness of R-MUD as an active addition for cement binders and as a part of cement to decrease the heat of hydration. Before using it in this way, appropriate durability and environmental tests should be performed.

After the analysis of the test results, it has been concluded that the replacement of up to $20 \%$ of cement with R-MUD does not affect the thermal heat development of the hydration process in comparison with pure cement.

The results of calorimetric tests indicate that the R-MUD participates in the hydration of binder. The silica, which has a significant specific surface, reacts with calcium hydroxide. The reaction accompanies the hydration process and results in the creation of cement grout microstructure.

Open Access This article is distributed under the terms of the Creative Commons Attribution 4.0 International License (http://crea tivecommons.org/licenses/by/4.0/), which permits unrestricted use, distribution, and reproduction in any medium, provided you give appropriate credit to the original author(s) and the source, provide a link to the Creative Commons license, and indicate if changes were made.

\section{References}

1. Nocun-Wczelik W, Malolepszy J. Application of calorimetry in studies of the immobilization of heavy metals in cementitious materials. Thermochim Acta. 1995;269(270):613-9.

2. Nocun-Wczelik W. Calorimetry in the studies of cement- $\mathrm{Pb}$ compounds interaction. J Therm Anal Calorim. 2007;88(1):291-4.

3. Lura P, Winnefeld F, Klemm S. Simultaneous measurements of heat of hydration and chemical shrinkage on hardening cement pastes. J Therm Anal Calorim. 2010;101:925-32.

4. Xueyu P, Bentz DP, Meyer C, Funkhouser GP, Darbe R. A comparison study of Portland cement hydration kinetics as measured by chemical shrinkage and isothermal calorimetry. Cem Concr Compos. 2013;39:23-32.

5. Nocun-Wczelik W. Heat evolution in hydrated cementitious systems admixtured with fly ash. J Therm Anal Calorim. 2001;65:613-9.

6. Dittrich S, Neubauer J, Goetz-Neunhoeffer F. The influence of fly ash on the hydration of OPC within the first $44 \mathrm{~h}-$ a quantitative in situ XRD and heat flow calorimetry study. Cem Concr Res. 2014;56:129-38.

7. Nocuń-Wczelik W. Heat evolution in alkali activated synthetic slag-metakaolin mixtures. J Therm Anal Calorim. 2006;86(3):739-43. 
8. Pacewska B, Wilińska I, Bukowska M, Nocuń-Wczelik W. Effect of waste aluminosilicate material on cement hydration and properties of cement mortars. Cem Concr Res. 2002;32:1823-30.

9. Contreras M, Jesús Gázquez M, García-Díaz I, Alguacil FJ, López FA, Bolívar JP. Valorisation of waste ilmenite mud in the manufacture of sulphur polymer cement. J Environ Manag. 2013; 128:625-30.

10. Puertas F, García-Díaz I, Palacios M, Gazulla MF, Gómez MP, Orduńa M. Clinkers and cements obtained from raw mix containing ceramic waste as a raw material. Characterization, hydration and leaching studies. Cem Concr Compos. 2010;32: 175-86.

11. Kurdowski W. Cement and concrete chemistry. Berlin: Springer; 2014.

12. Kurdowski W. The problem of compatibility of admixture with cement, another approach. Cem Wapno Beton. 2010;5:296-305.

13. Roekens EJ, van Grieken RE. Effects of titanium dioxide industry waste dumping on sea water chemistry. Water Res. 1983;17(10):1385-92.

14. Fauziah I, Zauyah S, Jamal T. Characterization and land application of red gypsum: a waste product from the titanium dioxide industry. Sci Total Environ. 1996;188:243-51.

15. Gázquez MJ, Bolívar JP, García-Tenorio R, Vaca F. Physicochemical characterization of raw materials and co-products from the titanium dioxide industry. J Hazard Mater. 2009;166: 1429-40.

16. Gázquez MJ, Mantero J, Bolívar JP, García-Tenorio R, Vaca F, Lozano RL. Physico-chemical and radioactive characterization of $\mathrm{TiO}_{2}$ undissolved mud for its valorization. J Hazard Mater. 2011;191:269-76.
17. Contreras M, Martín MI, Gázquez MJ, Romero M, Bolívar JP. Valorization of ilmenite mud waste in the manufacture of commercial. Ceram Constr Build Mater. 2014;72:31-40.

18. Gázquez MJ, Bolívar JP, Vaca F, Lozano RL, Barneto AG. Valorization of two industrial wastes from titanium industry as fire resistance building materials. Proceedings of the 3rd international CEMEPE and SECOTOX conference Skiathos, June 19-24. 2011. ISBN 978-960-6865-43-5.

19. Mostafa NY, Brown PW. Heat of hydration of high reactive pozzolans in blended cements: isothermal conduction calorimetry. Thermochim Acta. 2005;435:162-7.

20. Snelson DG, Wild S, O'Farrell M. Heat of hydration of Portland Cement-Metakaolin-Fly ash (PC-MK-PFA) blends. Cem Concr Res. 2008;38:832-40.

21. Pane I, Hansen W. Investigation of blended cement hydration by isothermal calorimetry and thermal analysis. Cem Concr Res. 2005;35:1155-64.

22. Pane I, Hansen W. Investigation on key properties controlling early-age stress development of blended cement concrete. Cem Concr Res. 2008;38:1325-35.

23. Witakowski P, Czamarska D, Bobrowicz J. Computerized system for calorimetric measurements. Part 1. Apparatus. Cem Wapno Gips. 1991;7:182-5 (in Polish).

24. Diot H, Bolle O, Lambert J-M, Launeau P, Duchesne J-C. The Tellnes ilmenite deposit (Rogaland, South Norway): magnetic and petrofabric evidence for emplacement of a Ti-enriched noritic crystal mush in a fracture zone. J Struct Geol. 2003;25:481-501. 